University of Nebraska - Lincoln

DigitalCommons@University of Nebraska - Lincoln

\title{
Regulation of Endometrial Granulocyte Macrophage-Colony Stimulating Factor (GM-CSF) in the Ewe
}

\author{
W. J. McGuire \\ Cloud County Community College \\ K. Imakawa \\ University of Tokyo \\ K. Tamura \\ Tokyo University of Pharmacy and Life Sciences \\ C. S. R. Meka \\ Oklahoma Medical Research Foundation \\ R. K. Christenson \\ USDA-ARS
}

Follow this and additional works at: https://digitalcommons.unl.edu/hruskareports

McGuire, W. J.; Imakawa, K.; Tamura, K.; Meka, C. S. R.; and Christenson, R. K., "Regulation of Endometrial Granulocyte Macrophage-Colony Stimulating Factor (GM-CSF) in the Ewe" (2002). Roman L. Hruska U.S. Meat Animal Research Center. 247.

https://digitalcommons.unl.edu/hruskareports/247

This Article is brought to you for free and open access by the U.S. Department of Agriculture: Agricultural Research Service, Lincoln, Nebraska at DigitalCommons@University of Nebraska - Lincoln. It has been accepted for inclusion in Roman L. Hruska U.S. Meat Animal Research Center by an authorized administrator of DigitalCommons@University of Nebraska - Lincoln. 


\title{
Regulation of endometrial granulocyte macrophage-colony stimulating factor (GM-CSF) in the ewe
}

\author{
W.J. McGuire ${ }^{\mathrm{a}, 1}$, K. Imakawa ${ }^{\mathrm{b}, 2}$, K. Tamura ${ }^{\mathrm{b}, 3}$, \\ C.S.R. Meka ${ }^{b, 4}$, R.K. Christenson ${ }^{\mathrm{a}, *}$ \\ ${ }^{a}$ USDA, Agricultural Research Service, Roman L. Hruska U.S. Meat Animal Research Center, \\ Clay Center, NE 68933-0166, USA \\ ${ }^{\mathrm{b}}$ Department of Pathology and Laboratory Medicine, University of Kansas Medical Center, \\ Kansas City, KS 66160-7410, USA
}

Received 16 October 2001; accepted 27 March 2002

\begin{abstract}
Granulocyte macrophage-colony stimulating factor (GM-CSF) increases ovine interferon-tau (oIFN $\tau)$ secretion by ovine conceptuses, but endometrial production of GM-CSF has not been characterized. Endometrial GM-CSF expression was evaluated in ovariectomized ewes implanted with estradiol-17 $\beta$ $\left(\mathrm{E}_{2}\right)$ and/or progesterone $\left(\mathrm{P}_{4}\right)$ for 14 days, in day 14 cyclic and day 14 pregnant ewes. Relative levels of endometrial GM-CSF mRNA were 3-fold higher in $\mathrm{E}_{2}$ - and $\mathrm{E}_{2} / \mathrm{P}_{4}$-treated ewes than that of control or $\mathrm{P}_{4}$-treated ovariectomized ewes. Levels of endometrial GM-CSF mRNA for cyclic ewes were similar to $\mathrm{E}_{2}$ - and $\mathrm{E}_{2} / \mathrm{P}_{4}$-treated ewes, but amounts of GM-CSF mRNA in pregnant ewes were 2-fold higher. GM-CSF concentrations in endometrial culture media, determined by GM-CSF bioassay, for cyclic and $\mathrm{E}_{2} / \mathrm{P}_{4}$-treated ovariectomized ewes were 3 -fold higher than those of control, $\mathrm{E}_{2}$ - and $\mathrm{P}_{4}$-treated ovariectomized ewes; however, amounts of GM-CSF in pregnant ewes were 2-fold higher. Immunoreactive GM-CSF, examined by western blot, was detected in the culture medium from $\mathrm{E}_{2} / \mathrm{P}_{4}$-treated ovariectomized, cyclic and pregnant ewes. Luminal and glandular epithelia and stromal regions were

\footnotetext{
Mention of trade names or commercial products in this article is solely for the purpose of providing specific information and does not imply recommendation or endorsement by the U.S. Department of Agriculture.

* Corresponding author. Tel.: +1-402-762-4192; fax: +1-402-762-4382.

E-mail address: christenson@email.marc.usda.gov (R.K. Christenson).

${ }^{1}$ Present address: Cloud County Community College, 2221 Campus Drive, P.O. Box 1002, Concordia, KS 66901-1002, USA.

${ }^{2}$ Present address: Laboratory of Animal Breeding, University of Tokyo, Tokyo 113-8657, Japan.

${ }^{3}$ Present address: Department of Pharmacology, Tokyo University of Pharmacy and Life Sciences, Hachioji, Tokyo 192-03, Japan.

${ }^{4}$ Present address: Immunobiology and Cancer Research, Oklahoma Medical Research Foundation, Oklahoma City, OK 73104, USA.
} 
determined to be sites of GM-CSF expression by immunohistochemistry and in situ hybridization techniques. Data indicate that combined $\mathrm{E}_{2}$ and $\mathrm{P}_{4}$ treatment of ovariectomized ewes is sufficient to restore GM-CSF expression to the level found in cyclic ewes; however, GM-CSF mRNA and protein in pregnant ewes is 2-fold greater than in ovariectomized or cyclic ewes. These data suggest that the conceptus, in addition to steroids, may play a role in the regulation of endometrial production of GM-CSF.

Published by Elsevier Science Inc.

\section{Introduction}

Ovine interferon-tau (oIFN $\tau$ ) is a conceptus signal that is implicated in the process of maternal recognition of pregnancy [1-4]. Accumulating data shows that oIFN $\tau$ production by the conceptus of ruminant ungulates is positively regulated by endometrially derived cytokine/growth factors [5,6]. One of these factors, granulocyte macrophage-colony stimulating factor (GM-CSF) [7], increases conceptus production of oIFN $\tau$ in vitro [8,9]. GM-CSF mRNA has been localized by in situ hybridization to luminal and glandular epithelia of the ovine uterus on day 14-16 of gestation [8]. In order for GM-CSF to manifest an effect on conceptus production of oIFN $\tau$, GM-CSF needs to be available for the conceptus in utero. The production of this protein in utero has not been well characterized.

GM-CSF production has been extensively studied in hematopoietic cells. Activation of $\mathrm{T}$-cells by recognition of antigens on antigen responding cells leads to rapid induction of a nuclear protooncogene, c-fos, followed by induction of a battery of lymphokine genes including interleukin-2 and GM-CSF [10,11]. Major events associated with T-cell activation that upregulate GM-CSF production are the activation of protein kinase $\mathrm{C}$ second messenger system and increased concentrations of free intracellular calcium [12,13]. This stimulation of GM-CSF levels appears to be the result of increased transcription, as the promoter region of GM-CSF contains two cis-acting elements, GM-кB/GC-box and conserved lymphokine element $\mathrm{O}$ (CLEO), that are required for maximal induction of the GM-CSF gene following stimulation with phorbol-12-myristate-13-acetate (PMA) or calcium ionophore (A23187) [14]. In addition, uterine epithelial cells were found to be another source of GM-CSF expression $[15,16]$. However, GM-CSF expression in cell types other than T-cells and an endocrine or paracrine factors(s) that directly regulates endometrial GM-CSF production have not been well characterized.

The steroid regulation of GM-CSF production from the ovine uterine endometrium has not been investigated. Ovine GM-CSF (oGM-CSF) production from the endometrium may be regulated partially by steroid hormones as demonstrated by Robertson et al. [16,17] when uterine epithelial production of GM-CSF was increased in ovariectomized mice by exogenous estrogens. Because estrogens elicit considerable uterine edema [18] and alter the cellular composition of the uterus [19], in situ techniques are required to determine the uterine source of growth factors/cytokines; resident endometrial cells, cells recruited to synthesize specific growth factors/cytokines and/or the influx of serum growth factors into the uterus. To ascertain endometrial production of GM-CSF, in addition to the presence of GM-CSF in uterine flushing medium, endometrial tissues need to be cultured in vitro and the culture media must be examined for the presence of GM-CSF. Therefore, using endometrial culture, 
immunohistochemistry and in situ hybridization methods, this study was undertaken to (1) determine the effects of estradiol-17 $\beta\left(\mathrm{E}_{2}\right)$ and/or progesterone $\left(\mathrm{P}_{4}\right)$ on the expression of endometrial GM-CSF in ovariectomized ewes, and (2) characterize endometrial expression of GM-CSF in cyclic and pregnant ewes. A newly developed antibody against oGM-CSF was used to detect and neutralize endometrial GM-CSF.

\section{Materials and methods}

\subsection{Animals}

Thirty mature, whiteface crossbred ewes were maintained in drylot pens and assigned to three experimental groups: (I) ovariectomized $(n=15)$, (II) day 14 cyclic $(n=7)$, and (III) day 14 pregnant $(n=8)$ ewes. Estrus was synchronized in all ewes using a 14-day treatment with an intravaginal sponge containing $40 \mathrm{mg}$ of $17 \alpha$-acetoxy- $9 \alpha$-fluoro- $11 \beta$-hydroxy $\mathrm{P}_{4}$. On the day of sponge removal, ewes were given an intramuscular injection of $10 \mathrm{mg} \mathrm{P}_{4}$. The following day, a second intramuscular injection of $10 \mathrm{mg} \mathrm{P}_{4}$ and a single subcutaneous injection of $500 \mathrm{IU}$ PMSG were administered [6].

On day 14 after the synchronized estrus (day $0=$ day of estrus), 12 group I ewes were anesthetized with xylazine hydrochloride $(0.1 \mathrm{mg} / \mathrm{lb})$ and lidocaine [6] and both ovaries were removed through a midventral laparotomy. After a 4-week recovery, ovariectomized ewes were aseptically implanted subcutaneously with the following treatments: control-blank silastic implants $(n=3)$, two $\mathrm{E}_{2}$ silastic implants $(n=3)$, three $\mathrm{P}_{4}$ elastomer implants $(n=3)$, or two $\mathrm{E}_{2}$ silastic and three $\mathrm{P}_{4}$ elastomer implants $(n=3)$, based on preliminary dose response results. Silastic implants were prepared from silastic medical grade tubing $(3.35 \mathrm{~mm} \times 4.65 \mathrm{~mm}$ OD; $8 \mathrm{~cm}$ total length; Dow Corning, Midland, MI, USA) that were filled with $\mathrm{E}_{2}$ [20]. Silicone elastomer implants (Sil-Estrus, Abbott Laboratories, North Chicago, IL, USA), each containing $375 \mathrm{mg} \mathrm{P}_{4}$, were used to provide $\mathrm{P}_{4}$. Blood samples from ovariectomized ewes were collected via jugular venipuncture prior to implant placement (day 0) and before hysterectomy on day 14 . Blood samples were allowed to clot at $4{ }^{\circ} \mathrm{C}$, and serum was collected by centrifugation and stored at $-20^{\circ} \mathrm{C}$ until assayed for concentrations of $\mathrm{P}_{4}$ and $\mathrm{E}_{2} . \mathrm{P}_{4}$ was assayed using a rabbit antiprogesterone-11 $\alpha$-bovine serum albumin (Cambridge medical Technology, Billerica, MA, USA) in one assay [21]. Estradiol-17 $\beta$ was assayed using an antiserum provided by N. R. Mason (Lilly Research Laboratories, Indianapolis, IN, USA) in one assay [22]. On day 14 of implant treatment, group I ewes were anesthetized as previously described and hysterectomy was performed. Group II ewes were monitored for estrus with vasectomized rams fitted with marking harnesses, and estrus was recorded twice daily. Group III ewes were monitored for estrus and mated by two fertile rams fitted with marking harnesses, and estrus and mating were recorded twice daily. Hysterectomies were performed on group II ewes on day 14 of the estrous cycle and on group III ewes on day 14 after mating.

\subsection{Tissue culture}

After hysterectomy, uteri were immediately placed on ice and uteri from all ewes were transported to the laboratory and processed within $15 \mathrm{~min}$. Uteri of pregnant ewes were flushed 
with 20-30 mL sterile phosphate-buffered saline (PBS, pH 7.2) to recover conceptuses. Conceptuses were removed from the flushing media and protease inhibitor (PMSF, $1 \mathrm{mM}$ ) was added to each uterine flush before freezing (liquid nitrogen) and storing at $-80^{\circ} \mathrm{C}$ for later GM-CSF analysis by bioassay (described later). Endometrial tissue was stripped from the uterus, minced, and an equal mass of tissue (300 mg wet weight, three culture dishes per ewe) from each implant-treated ovariectomized, cyclic and pregnant ewe was cultured in $10 \mathrm{~mL}$ Eagle's minimum essential medium (Sigma Chemical Co., St. Louis, MO, USA). All samples were cultured at $37^{\circ} \mathrm{C}$ on a rocking platform under $50 \% \mathrm{~N}_{2}, 45 \% \mathrm{O}_{2}$, and $5 \% \mathrm{CO}_{2}$. Following a $24 \mathrm{~h}$ culture period, endometrium was collected by centrifugation at $2500 \mathrm{rpm}$ for $5 \mathrm{~min}$. Culture medium was collected and stored at $-20^{\circ} \mathrm{C}$, and cultured endometrial samples were frozen in liquid nitrogen and stored at $-80^{\circ} \mathrm{C}$ until RNA extraction was performed.

\subsection{Quantitation of GM-CSF $m R N A$}

Total RNA was extracted from $300 \mathrm{mg}$ of cultured endometrial tissue samples according to the method of Chomzynski and Sacchi [23]. After spectrophotometric quantitation of samples, integrity of extracted RNA was confirmed by the presence of distinct $18 \mathrm{~s}$ and $28 \mathrm{~s}$ rRNA bands through an agarose gel electrophoresis containing ethidium bromide $(2 \mu \mathrm{g} / \mathrm{mL})$ to visualize the RNA [24]. Relative levels of GM-CSF mRNA were quantitated by reverse transcription-polymerase chain reaction (RT-PCR) method as described by Nephew et al. [25]. Preliminary experiments were performed to validate the primer specificity and PCR conditions under which each amplification reaction was confined to the exponential phase. For the determination of primer specificity, endometrial RNA samples ( $5 \mu \mathrm{g}$ each) from group I, II and III ewes were treated with RNase free DNase (Stratagene, South San Francisco, CA, USA) and then reverse transcribed with AMV reverse transcriptase (Promega, Madison, WI, USA) in the presence of a $3^{\prime}$-downstream primer corresponding to bp 340-361 (5'-CTG GGT TTC ACA GGA AGT TTC C-3') [26]. The resulting cDNA was amplified through 30 cycles (94:60:74 $\mathrm{C}$ for 1,1 , and $2 \mathrm{~min}$, respectively) of PCR using a $5^{\prime}$-upstream primer corresponding to bp 14-33 (5'ATG TGG CTG CAG AAC CTG CT-3'). The amplification products were electrophoresed on a $1.5 \%$ agarose gel containing ethidium bromide $(10 \mu \mathrm{g} / \mathrm{mL})$ to visualize a $348 \mathrm{bp}$ band. The PCR products were eluted from the agarose gel, cloned into pBS vector (Stratagene, South San Francisco, CA, USA) and nucleotides were determined by dideoxy sequencing method (Sequenase, Amersham Life Science, Cleveland, OH, USA) [27]. Nucleotide sequences confirmed that these primers were specific for the detection of oGM-CSF mRNA. For cRNA standard preparation, oGM-CSF cDNA (500 bp; C.J. McInnes, Moredun Research Institute, Edinburgh, UK) was appropriately linearized and sense strand oGM-CSF cRNA was produced by an in vitro transcription [24,25]. cRNA standards, ranging from 0.01 to $60 \mathrm{pg}$, were reverse transcribed using the $3^{\prime}$-downstream primer as aforementioned. Resulting cDNAs were amplified with the upstream primer labeled with ${ }^{32} \mathrm{P}-\gamma$-dATP (specific activity $6000 \mathrm{Ci} / \mathrm{mmol}$; Dupont NEN, Boston, MA, USA). PCR was carried out 20-25 cycles to yield PCR products proportional to the initial concentrations of cRNA. Amplified products were examined on an agarose gel and incorporated radioactivity was determined by liquid scintillation counting [25,28,29]. Levels of cRNA standard were plotted against radioactivity (cpm); data were also plotted against PCR cycle number, and a linear line was fitted to each 
curve [30]. RNA samples along with cRNA standards ranging from 0.1 to $30 \mathrm{pg}$ were reverse transcribed with the downstream primer. The resulting cDNA was amplified for 22 cycles using the upstream primer, which had been validated to be proportional to the range $(0.1-30 \mathrm{pg})$ of cRNA standard. Control reactions, RNA without reverse transcriptase and PCR without cDNA template were run in parallel, which resulted in no PCR product. Levels of GM-CSF mRNA for RNA samples were then calculated from the standard curve.

\subsection{Bioassay of GM-CSF}

After endometrial culture, whole medium samples $(10 \mathrm{~mL} / \mathrm{culture})$ along with oGM-CSF enriched conditioned media prepared from COS-1 monkey kidney cells (oGM-CSF CM, C.J. McInnes) were dialyzed in the presence of protease inhibitors, pepstatin A $(0.7 \mathrm{mg} / \mathrm{mL})$ and leupeptin-propionyl $(0.35 \mathrm{mg} / \mathrm{mL})$. A total of $500 \mu \mathrm{L}$ endometrial culture media was used for a bioassay and the remaining medium $(9.5 \mathrm{~mL})$ and oGM-CSF CM upon concentration were subjected to western blot analysis. Concentrations of oGM-CSF in endometrial culture and uterine flushing media were quantified by a proliferation bioassay using GM-CSF dependent TF-1 cells [31] supplied by L. Guilbert (Department of Immunology, University of Alberta, Alberta, Canada). TF-1 cells were grown in RPMI medium 1640 (Gibco BRL, Grand Island, NY, USA) containing $10 \%$ fetal bovine serum (FBS) and $5 \mathrm{ng} / \mathrm{mL}$ human recombinant GM-CSF (hrGM-CSF; Genetics Institute, Cambridge, MA, USA). Before GM-CSF assay, these cells were deprived of hrGM-CSF for $24 \mathrm{~h}$. Four thousand TF- 1 cells, prepared in $50 \mu \mathrm{L}$ RPMI 1640 medium, were added to hrGM-CSF standard $(5,10,20,40,80,160$, 320 , and $660 \mathrm{pg} / \mathrm{mL}$ ), endometrial culture samples, and uterine flushing samples in triplicate. The final volume $(150 \mu \mathrm{L}$, which contained $10 \% \mathrm{FBS})$ was cultured at $37^{\circ} \mathrm{C}$ under the conditions of $95 \%$ air and $5 \% \mathrm{CO}_{2}$ for 3 days. On day 4 of the culture, $5 \mu \mathrm{L}$ RPMI 1640 containing $1 \mu \mathrm{Ci}^{3} \mathrm{H}$-thymidine (specific activity 70-90 Ci/mmol; DuPont NEN, Boston, MA, USA) and 10\% FBS (Sigma Chemical Co., St. Louis, MO, USA) were added to each well and incubated for $4 \mathrm{~h}$. The cells were harvested in a cell-harvester fitted with filter paper (DE81, Whatman International, Ltd., Maidstone, UK) to measure ${ }^{3} \mathrm{H}$-thymidine incorporation. A total of eight standards were placed at the beginning, middle, and end of each plate. In order to assess assay variation, oGM-CSF CM and pooled endometrial culture media in triplicate were included in each assay. Assay sensitivity was 23 pg per well and the intra and interassay coefficient of variation, calculated from the values of GM-CSF CM and pooled samples within and between assays, were 6.2 and $9.1 \%$, respectively. To determine the specificity of the bioassay, an antibody against oGM-CSF (described later) was prepared and used to neutralize hrGM-CSF, oGM-CSF CM and oGM-CSF from endometrial culture media. More than $95 \%$ of GM-CSF, regardless of species, was neutralized with this azide-free antiserum.

\section{5. oGM-CSF antibody production and western blot analysis}

An antibody to a synthetic peptide representing a portion of oGM-CSF was developed using the following strategy: an antigenic site along the deduced amino acid sequence of oGM-CSF [26] was determined by assigning each amino acid hydrophilicity values. The point of the 
highest local average hydrophilicity is invariably located in, or immediately adjacent to, an antigenic determinant $[32,33]$. An antiserum to that domain prepared by Research Genetics (Huntsville, AL, USA) is ETQIITFKSFKENLKD, which is equivalent to a region found in hrGM-CSF [34].

After dialysis, $9.5 \mathrm{~mL}$ samples of endometrial culture media or $3 \mathrm{~mL}$ samples of oGM-CSF CM were concentrated by Centricon (Amicon, Beverly, MA, USA), separated by $12.5 \%$ SDS-PAGE and then electrotransferred to Immobilon (Millipore, Bedford, MA, USA) [6]. The filters were blocked with $5 \%$ nonfat dry milk in Tris-buffered saline containing $0.1 \%$ Tween-20 (TBST). The filters were then incubated with rabbit preimmune serum or anti-oGM-CSF antibody at a dilution of 1:1000 in TBST. The immunoreactive proteins were detected using alkaline-phosphatase conjugated to rabbit IgG antibody.

\subsection{In situ hybridization and immunohistochemistry}

In addition to endometrial tissues subjected to in vitro culture study, a $0.125 \mathrm{~cm}^{3}(0.5 \mathrm{~cm} \times$ $0.5 \mathrm{~cm} \times 0.5 \mathrm{~cm}$ ) section of uterus from all treatment groups was fixed, paraffin embedded, sectioned and evaluated for the presence of GM-CSF mRNA and its protein. In situ hybridization was performed as previously described [6,8]. Briefly, oGM-CSF cDNA (C.J. McInnes) of which a portion of the $3^{\prime}$ region had been subcloned into pBS M13 [8,26], was appropriately linearized and sense and antisense GM-CSF cRNA probes were produced using T3 and T7 RNA polymerases, respectively. Digoxigenin-11 UTP (Boehringer Mannheim, Indianapolis, IN, USA) was incorporated into the probes during in vitro transcription. Binding of oGM-CSF cRNA to endometrial tissues was detected by antidigoxigenin antibody conjugated with alkaline phosphatase (Boehringer Mannheim, Indianapolis, IN, USA). Sections were then counterstained with methyl green.

Immunohistochemistry was performed with the oGM-CSF antiserum described previously. Briefly, a rabbit polyclonal antibody to the oGM-CSF oligopeptide was used at a dilution of 1:250 in PBS, and binding was detected by means of an avidin-biotin immunoperoxidase staining kit [6]. 3-amino-9-ethylcarbazole in N,N-dimethylformamide (Zymed Laboratories, Inc., South San Francisco, CA, USA) was used as substrate for the peroxidase, and positive cells were identified by the presence of a reddish-brown reaction product. An equal concentration of preimmune serum was used on semiserial sections of the same tissue to evaluate nonspecific binding of the avidin-biotin immunoperoxidase. Tissue sections were then counterstained with hematoxylin.

\subsection{Statistical analysis}

Data obtained from ovariectomized, cyclic and pregnant ewes were analyzed as a one-way analysis of variance [30] of six treatment groups (i.e., ovariectomized control (1), ovariectomized plus $\mathrm{E}_{2}$ implant (2), ovariectomized plus $\mathrm{P}_{4}$ implant (3), ovariectomized plus $\mathrm{E}_{2}$ and $\mathrm{P}_{4}$ implants (4), cyclic (5), and pregnant (6)). The sums of squares were partitioned into single degree of freedom contrasts ((1) versus (2), (1) versus (3), (1) versus (4), (4) versus (5), (5) versus (6), and (4) versus (6)) that had been selected a priori to compare the treatment groups. 
Table 1

Serum concentrations of $\mathrm{E}_{2}$ and $\mathrm{P}_{4}$ before and after $\mathrm{E}_{2}$ and/or $\mathrm{P}_{4}$ treatment in group I ovariectomized ewes

\begin{tabular}{|c|c|c|c|c|}
\hline \multirow[t]{2}{*}{ Treatment } & \multicolumn{2}{|c|}{$\mathrm{E}_{2}(\mathrm{pg} / \mathrm{mL})$} & \multicolumn{2}{|l|}{$\mathrm{P}_{4}(\mathrm{ng} / \mathrm{mL})$} \\
\hline & Day $0^{\mathrm{a}}$ & Day $14^{\mathrm{a}}$ & Day $0^{\mathrm{a}}$ & Day $14^{a}$ \\
\hline Control & $4.6 \pm 0.4$ & $6.4 \pm 1.5$ & $0.04 \pm 0.01$ & $0.21 \pm 0.15$ \\
\hline $\mathrm{E}_{2}$ & $5.7 \pm 1.0$ & $40.5 \pm 6.2$ & $0.07 \pm 0.02$ & $0.08 \pm 0.03$ \\
\hline $\mathrm{P}_{4}$ & $4.1 \pm 0.3$ & $5.4 \pm 0.24$ & $0.07 \pm 0.04$ & $2.27 \pm 0.31$ \\
\hline $\mathrm{E}_{2} / \mathrm{P}_{4}$ & $6.2 \pm 0.9$ & $46.4 \pm 10.3$ & $0.09 \pm 0.01$ & $1.51 \pm 0.52$ \\
\hline
\end{tabular}

Mean \pm SEM.

${ }^{a}$ Blood samples were collected before implanting ewes on day 0 and before hysterectomy on day 14 .
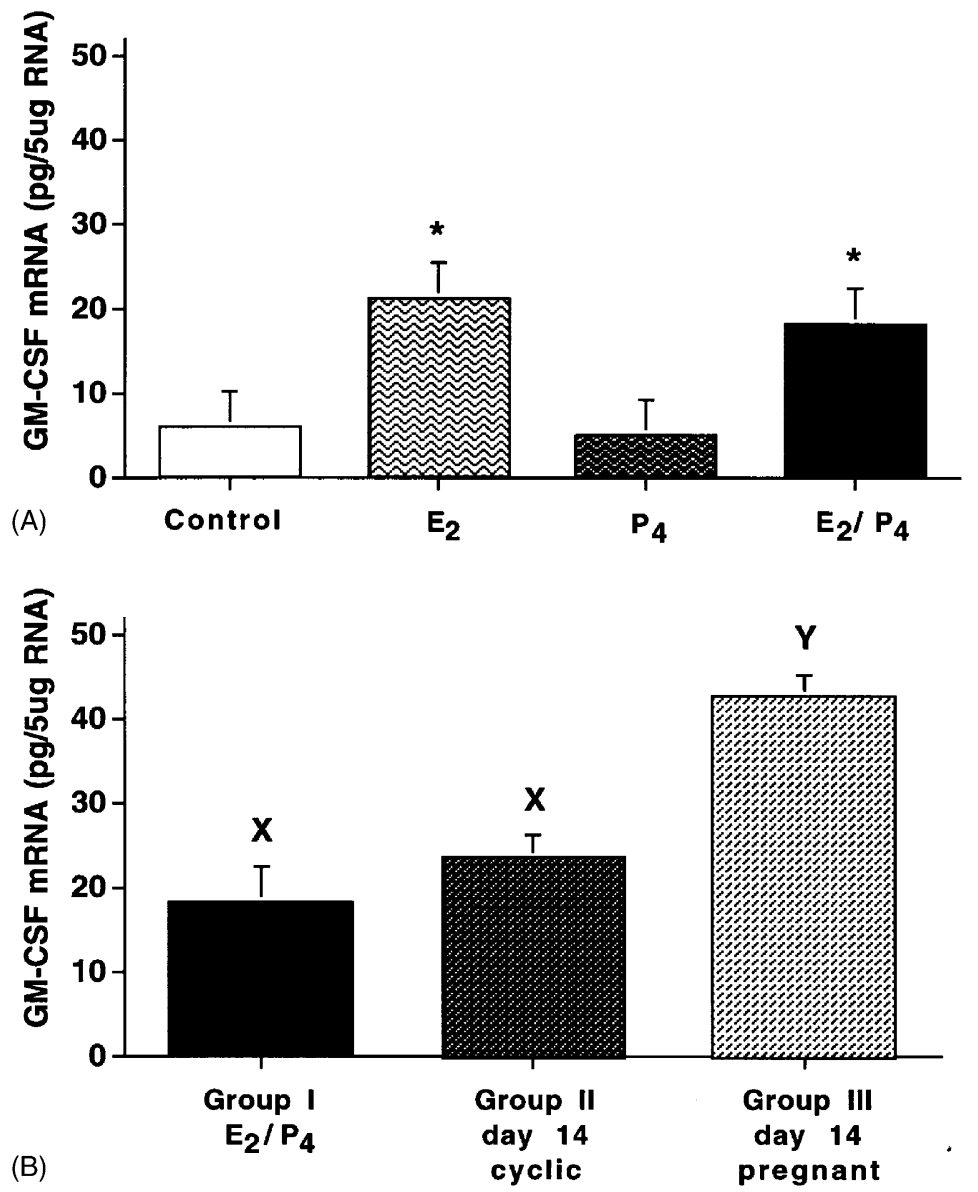

Fig. 1. Mean ( \pm SEM) levels of GM-CSF mRNA in cultured endometrium from group I, II and III ewes. RNA was isolated from cultured endometrium and subjected to quantitative RT-PCR. (A) Depicts group I, ovariectomized ewes assigned to the following treatments: controls, $E_{2}, P_{4}$ and $E_{2} / P_{4}$. (B) Depicts group I ( $\left.E_{2} / P_{4}\right)$, group II (day 14 cyclic) and group III (day 14 pregnant) ewes. (*) Indicates that the mean is different from control $(P<0.05)$. Means having different superscripts $(\mathrm{x}, \mathrm{y}) \operatorname{differ}(P<0.01)$. 


\section{Results}

Mean serum concentrations of $\mathrm{E}_{2}$ and $\mathrm{P}_{4}$ in group I ovariectomized ewes, as determined by specific RIA on days 0 and 14, are shown in Table 1 . Serum concentrations of $\mathrm{E}_{2}$ and $\mathrm{P}_{4}$ did not differ between day 0 and 14 in ovariectomized ewes that did not receive $\mathrm{E}_{2}$ or $\mathrm{P}_{4}$ implants. Serum concentrations of $\mathrm{E}_{2}$ in the $\mathrm{E}_{2}$ - and $\mathrm{E}_{2} / \mathrm{P}_{4}$-treated ovariectomized ewes on day 14 were $40.5 \pm 6.2$ and $46.4 \pm 10.3 \mathrm{pg} / \mathrm{mL}$, respectively. Similarly, serum concentrations of $\mathrm{P}_{4}$ in the $\mathrm{P}_{4}$ - and $\mathrm{E}_{2} / \mathrm{P}_{4}$-treated ewes on day 14 were $2.27 \pm 0.31$ and $1.51 \pm 0.52 \mathrm{ng} / \mathrm{mL}$, respectively.

After RT-PCR of GM-CSF cRNA standards (0.1-30 pg), levels of cRNA were plotted versus cpm producing a linear standard curve with an $r^{2}$ of $0.993(y=-7091.7+1.6876 x)$. The incorporated cpm $(3000-65,000 \mathrm{cpm})$ resulting from RT-PCR of RNA samples yielded values that fell within the standard curve $(0.1-30 \mathrm{pg})$. Levels of GM-CSF mRNA extracted from cultured endometrial tissues obtained from $\mathrm{E}_{2}$ - and $\mathrm{E}_{2} / \mathrm{P}_{4}$-treated ovariectomized ewes were
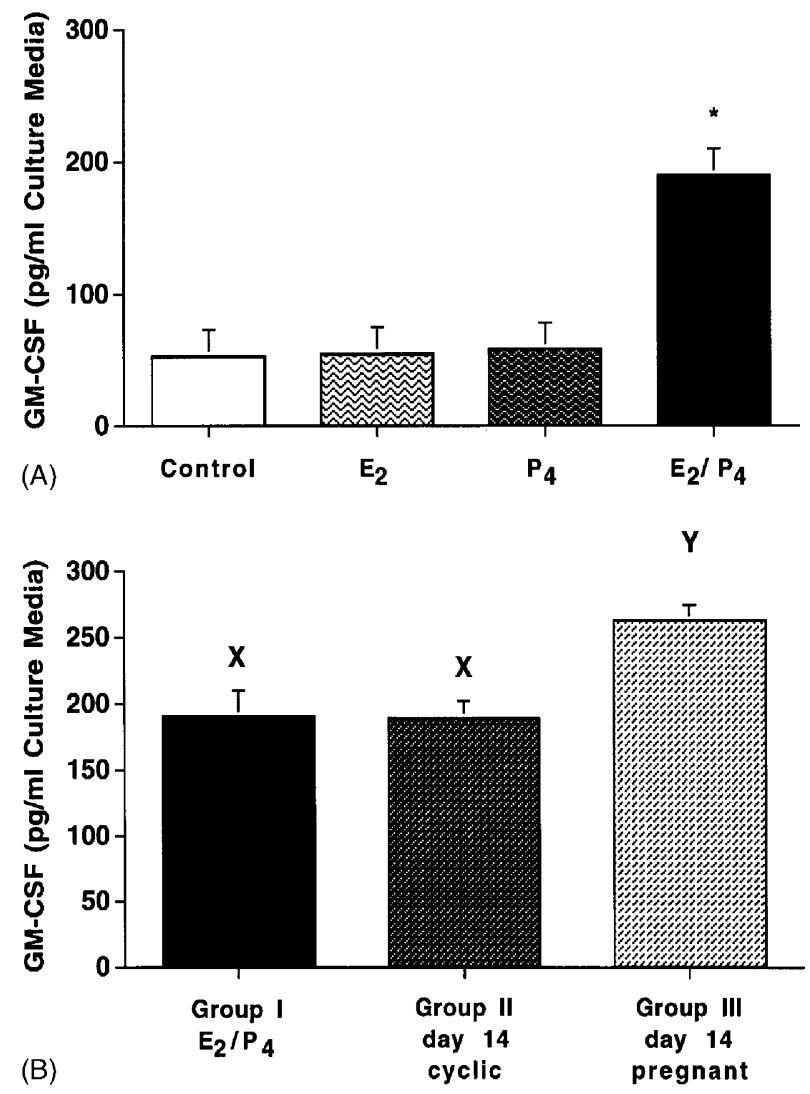

Fig. 2. Mean ( \pm SEM) concentrations of bioactive GM-CSF in medium from cultured endometrium from group I, II and III ewes. GM-CSF was determined by bioassay based on proliferation of GM-CSF dependent TF-1 cells. (A) Depicts group I, ovariectomized ewes assigned to the following treatments: control, $\mathrm{E}_{2}, \mathrm{P}_{4}$ and $\mathrm{E}_{2} / \mathrm{P}_{4}$. (B) Depicts group I $\left(\mathrm{E}_{2} / \mathrm{P}_{4}\right)$, group II (day 14 cyclic) and group III (day 14 pregnant) ewes. (*) Indicates that the mean is different from control $(P<0.01)$. Means having different superscripts $(\mathrm{x}, \mathrm{y}) \operatorname{differ}(P<0.01)$. 
higher $(P<0.05)$ than those seen in controls (Fig. 1A). GM-CSF mRNA levels extracted from cultured endometrial tissues from $\mathrm{P}_{4}$-treated ovariectomized ewes were not different from controls. GM-CSF mRNA levels from cultured endometrial tissues from $\mathrm{E}_{2} / \mathrm{P}_{4}$-treated ovariectomized and cyclic ewes were less $(P<0.01)$ than that of pregnant ewes (Fig. 1B).

GM-CSF concentrations, determined by a bioassay, in endometrial culture media obtained from either $\mathrm{E}_{2}$ - or $\mathrm{P}_{4}$-treated ovariectomized ewes were not different from those seen in controls (Fig. 2A). The combined treatment of $\mathrm{E}_{2} / \mathrm{P}_{4}$ resulted in a 3 -fold increase $(P<0.01)$ in GM-CSF secreted into culture media as compared to that of control ovariectomized ewes. However, GM-CSF concentrations in endometrial culture media obtained from $\mathrm{E}_{2} / \mathrm{P}_{4}$-treated ovariectomized and cyclic ewes were similar and both of these were less $(P<0.01)$ than that of pregnant ewes (Fig. 2B). In addition, GM-CSF detected in the uterine flushing media (23 mL) obtained from pregnant ewes was $86 \pm 21 \mathrm{pg} / \mathrm{mL}$, resulting in approximately $2 \pm 0.5 \mathrm{ng}$ in utero at the time of hysterectomy.

Results of GM-CSF western blot analysis are presented in Fig. 3. The anti-oGM-CSF antibody detected a band approximately $23 \mathrm{kDa}$ in size in endometrial culture medium, which is in agreement with the value for mouse native GM-CSF reported in a previous study [7]. Immunoreactive GM-CSF was detected in samples of endometrial culture media from the $\mathrm{E}_{2} / \mathrm{P}_{4}$-treated ovariectomized, cyclic and pregnant ewes and not in endometrial culture media from control, $\mathrm{E}_{2}$ - or $\mathrm{P}_{4}$-treated ovariectomized ewes.

45

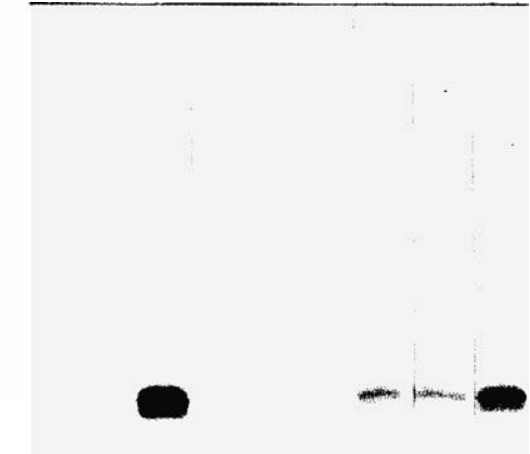

14.5

$\begin{array}{lllllllll}1 & 2 & 3 & 4 & 5 & 6 & 7 & 8 & 9\end{array}$

Fig. 3. Western blot analysis of GM-CSF released into culture medium from endometrium of ovariectomized, cyclic and pregnant ewes. Endometrial culture media $(9.5 \mathrm{~mL})$ and oGM-CSF enriched conditioned media (oGM-CSF CM) were dialyzed, concentrated, separated by $12.5 \%$ SDS-PAGE and transferred to filters. Filters were incubated with rabbit preimmune serum or anti-oGM-CSF antiserum, and immunoreactive proteins detected by alkaline phosphatase conjugated to rabbit IgG antibody. Lane (1) Mr markers, (2) oGM-CSF CM with preimmune serum, (3) oGM-CSF CM with the anti-oGM-CSF antiserum, (4) control-ovariectomized ewe, (5) $\mathrm{E}_{2}$-treated ovariectomized ewe, (6) $\mathrm{P}_{4}$-treated ovariectomized ewe, (7) $\mathrm{E}_{2} / \mathrm{P}_{4}$-treated ovariectomized ewe, (8) day 14 cyclic ewe, and (9) day 14 pregnant ewe. 


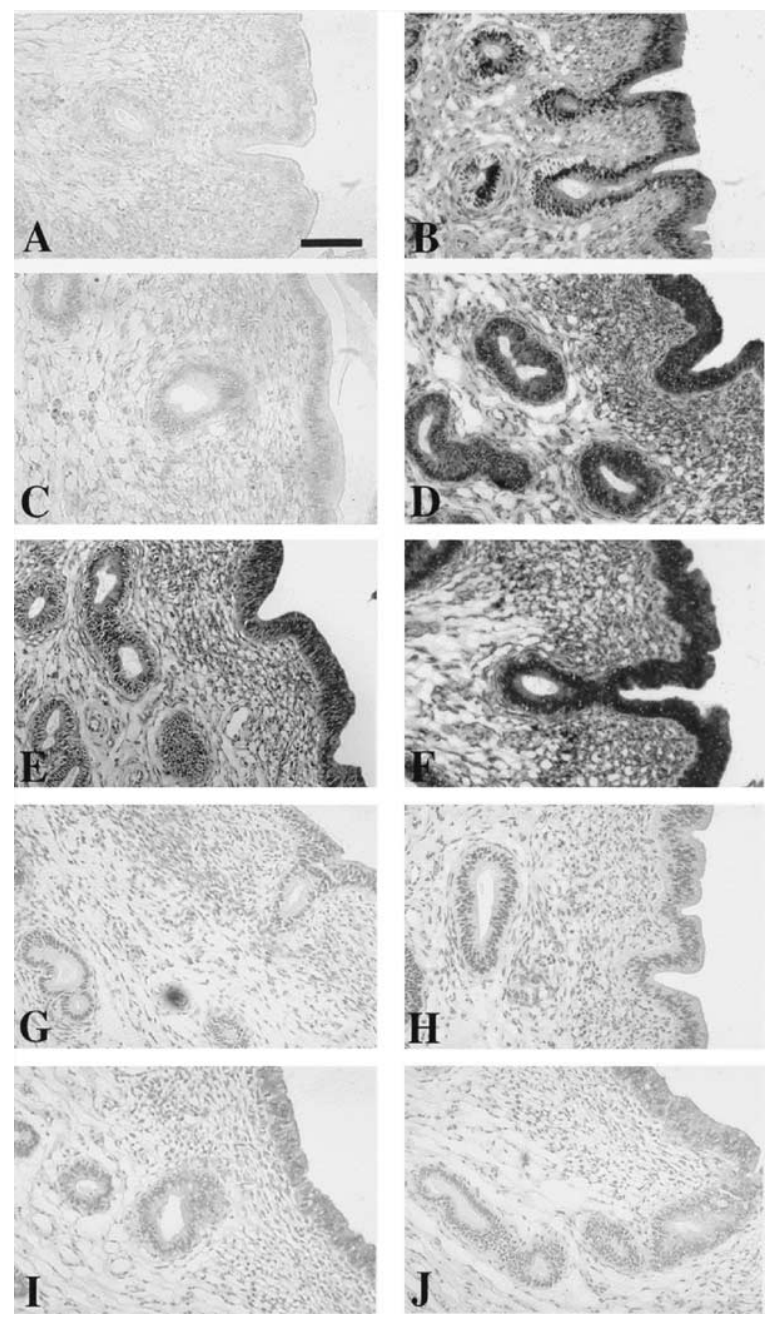

Fig. 4. Localization of oGM-CSF mRNA and its protein to uterine endometria from ovariectomized, cyclic, and pregnant ewes. Bar $=100 \mu \mathrm{m}$; all micrographs are same magnification. Cellular localization of oGM-CSF mRNA by: (A) oGM-CSF sense cRNA probe to semiserial section from day 14 pregnant ewe (no hybridization), (B) oGM-CSF antisense cRNA probe to section from $\mathrm{E}_{2}$-treated ovariectomized ewe (hybridization), (C) oGM-CSF antisense cRNA probe to section from $\mathrm{P}_{4}$-treated ovariectomized ewe (no hybridization), (D) oGM-CSF antisense cRNA probe to section from $\mathrm{E}_{2} / \mathrm{P}_{4}$-treated ovariectomized ewe (hybridization), (E) oGM-CSF antisense cRNA probe to section from a day 14 cyclic ewe (hybridization), (F) oGM-CSF antisense cRNA probe to semiserial section (see (A)) from a day 14 pregnant ewe (hybridization). Because no hybridization was observed, endometrial section from control-ovariectomized ewe are not shown. Immunohistochemical localization of oGM-CSF by: (G) preimmune rabbit serum (negative control) to semiserial section from day 14 pregnant ewe (no staining), $(\mathrm{H})$ anti-oGM-CSF antiserum to section from $\mathrm{E}_{2}$-treated ovariectomized ewe (no staining), (I) anti-oGM-CSF antiserum to section from $\mathrm{E}_{2} / \mathrm{P}_{4}$-treated ovariectomized ewe (staining), (J) anti-oGM-CSF antiserum to semiserial section (see (G)) from day 14 pregnant ewe (staining). Because no staining was observed, endometrial sections from control or $\mathrm{P}_{4}$-treated ovariectomized ewe are not shown. 
Results of in situ hybridization and immunohistochemical analyses for GM-CSF are presented in Fig. 4. Results from in situ hybridization studies agreed with GM-CSF mRNA levels detected by RT-PCR (Fig. 1), with the positive staining being observed in sections of uteri obtained from pregnant, cyclic and $\mathrm{E}_{2}-$ and $\mathrm{E}_{2} / \mathrm{P}_{4}$-treated ovariectomized animals. Similar to the previous results [8], GM-CSF mRNA was localized to the luminal and glandular epithelial and stromal regions. Minimal to nondetectable staining was observed in tissues obtained from the control and $\mathrm{P}_{4}$-treated ovariectomized ewes.

GM-CSF protein was detected at the luminal and glandular epithelia in endometrial sections obtained from ewes in the $\mathrm{E}_{2} / \mathrm{P}_{4}$-treated ovariectomized, cyclic, and pregnant animals (Fig. 4). No staining was associated with the luminal and glandular epithelia of endometrial tissues from the control or $\mathrm{P}_{4}$-treated ovariectomized ewes. However, minor staining of GM-CSF was noted at the edge of luminal epithelium in one of three $E_{2}$-treated ovariectomized animals while no staining was observed in the endometrium of the remaining $\mathrm{E}_{2}$-treated ovariectomized ewes. These results were in close agreement with the results of the bioassay (Fig. 2) and western blot analysis (Fig. 3), which indicated that GM-CSF protein was present in appreciable quantities in the $\mathrm{E}_{2} / \mathrm{P}_{4}$-treated ovariectomized, cyclic and pregnant ewes.

\section{Discussion}

In ovariectomized ewes, the implants produced serum concentrations of $\mathrm{P}_{4}$ that mimicked those seen in vivo during the late luteal phase or early pregnancy in ewes [35]. Concentrations of $E_{2}$ in serum of ovariectomized ewes with $E_{2}$ implants were higher than previously reported. However, the magnitude of increase in serum concentrations of $E_{2}$ produced by the $\mathrm{E}_{2}$ implants was similar to that shown by Karsch et al. [20] and Goodman et al. [35]. The steroid environment produced by the implants was maintained for 14 days, which should have adequately allowed for any necessary steroid priming of the endometrium. It should be noted that by pathological examination, the $\mathrm{E}_{2} / \mathrm{P}_{4}$ regimen utilized in this study were not found to cause uterine edema or to alter the cellular composition of the uterus (I. Damjanov, University of Kansas Medical Center, Kansas City, KS, USA). Therefore, GM-CSF expression in $\mathrm{E}_{2}$ - or $\mathrm{E}_{2} / \mathrm{P}_{4}$-treated ovariectomized ewes observed in the present study did not result from pharmacological or confounding effects of $E_{2}$.

Treatment of ovariectomized ewes with $\mathrm{E}_{2}$ implants stimulated increases in levels of endometrial GM-CSF mRNA, presumably through increased transcription and/or message stability [36]. Although $\mathrm{P}_{4}$ diminishes GM-CSF mRNA synthesis in the mouse [16], $\mathrm{P}_{4}$ treatment alone, when implanted for 14 days in sheep, did not stimulate or inhibit endometrial GM-CSF mRNA or protein levels. Although GM-CSF mRNA levels were elevated in endometrium obtained from $E_{2}$-treated ewes, no additional increase in GM-CSF protein was detected in these animals and, therefore, GM-CSF protein levels remained similar to controls. $\mathrm{P}_{4}$ treatment along with $\mathrm{E}_{2}$ in the ovariectomized ewes increased GM-CSF protein to the level detected in cyclic ewes. However, the degree of GM-CSF expression in $\mathrm{E}_{2} / \mathrm{P}_{4}$-treated ovariectomized and cyclic ewes was still less than that of pregnant animals. These data suggest that the combined $\mathrm{E}_{2}$ and $\mathrm{P}_{4}$ treatment of ovariectomized ewes sufficiently restores GM-CSF expression to the level of cyclic ewes and that the conceptus may play a role in the regulation of GM-CSF expression in 
utero. Higher GM-CSF levels detected in pregnant animals agree with the recent observations in which oIFN $\tau$ enhanced endometrial GM-CSF [37]. Additionally, detection of GM-CSF protein in the uterine flushing indicates that bioactive protein, at least by the bioassay of the TF- 1 cells, is present in utero. The fact that GM-CSF is not detected in the ovine conceptuses [6] further confirms that the source of GM-CSF production is the uterine endometrium. The present study also confirms the results by Giacomini et al. [15] and Robertson et al. [16] in which GM-CSF expression in utero occurs at the luminal and glandular epithelial cells, not by lymphocytes recruited by the endometrium.

These results indicate that the steroidogenic environment of early pregnancy should be capable of inducing the expression of endometrial GM-CSF, which in turn has been demonstrated to increase oIFN $\tau$ production from the ovine conceptus [6,8]. The molecular mechanism(s) by which the conceptus upregulates endometrial expression of GM-CSF during early conceptus development is still unclear. However, oIFN $\tau$ could be a factor that enhances endometrial GM-CSF production [37]. To study the effect of conceptus and/or conceptus secretory protein(s) on endometrial production of GM-CSF is beyond the scope of the present investigation. However, this localized production of bioactive GM-CSF that is readily available to the conceptus provides further evidence for the existence of a biochemical network of embryo-maternal communication.

\section{Acknowledgments}

The authors thank Dr. I. Damjanov, Department of Pathology and Laboratory Medicine, for his careful evaluation of uterine tissues for the presence of edema or unusual cells, L.A. Harbison and D. Sypherd for assistance in the laboratory and L. Parnell for careful preparation of the manuscript. We thank Drs. R.J. Kittok and J.E. Kinder for estrogen RIA assistance, Dr. L. Guilbert for TF-1 cells, Dr. C.J. McInnes for oGM-CSF cDNA and oGM-CSF enriched conditioned media, and the Genetics Institute for hrGM-CSF. We also appreciate the dedicated support of sheep operations personnel at the Roman L. Hruska U.S. Meat Animal Research Center. These studies were initially supported in part by funds from the Women's Research Institute, Wesley Medical Research Institute, the Maizie Wilkonson Memorial Endowed Funds for Cancer Research, and the University of Kansas Medical Center Endowment Funds.

\section{References}

[1] Moor RM, Rowson LEA. The corpus luteum of the sheep: functional relationship between the embryo and the corpus luteum. J Endocrinol 1966;34:233-9.

[2] Martal J, Lacroix MC, Loudes C, Saunier M, Wintenberger-Torres S. Trophoblastin, an antiluteolytic protein present in early pregnancy in sheep. J Reprod Fertil 1979;56:63-73.

[3] Godkin JD, Bazer FW, Moffat J, Sessions F, Roberts RM. Purification and properties of a major, low molecular weight protein released by the trophoblast of sheep blastocysts on day 13-21. J Reprod Fertil 1982;65:141-50.

[4] Roberts RM, Cross JC, Leaman DW. Interferons as hormones of pregnancy. Endocr Rev 1992;13:432-52.

[5] Hernandez-Ledezma JJ, Sikes JD, Murphy CN, Watson AJ, Schultz GA, Roberts RM. Expression of bovine trophoblast interferon in conceptuses derived by in vitro techniques. Biol Reprod 1992;47:374-80.

[6] Imakawa K, Tamura K, McGuire WJ, Khan S, Harbison LA, Stanga JP, Helmer SD, Christenson RK. Effect of interleukin-3 on ovine trophoblast interferon during early conceptus development. Endocrine 1995;3:511-7. 
[7] Metcalf D. The granulocyte-macrophage colony-stimulating factors. Science 1985;229:16-22.

[8] Imakawa K, Helmer SD, Nephew KP, Meka CSR, Christenson RK. A novel role for GM-CSF: enhancement of pregnancy specific interferon production, ovine trophoblast protein-1. Endocrinology 1993;132:1869-71.

[9] Imakawa K, Helmer SD, Harbison LA, Meka CSR, Christenson RK. Hemopoietic cytokine regulation of trophoblast interferon, ovine trophoblast protein-1. In: Glasser SR, Mulholland J, Psychoyos A, editors. Endocrinology of embryo-endometrium interactions. New York: Plenum, 1994. p. 167-81.

[10] Ullman KS, Northrop JP, Verweij CL, Crabtree GR. Transmission of signals from the T lymphocyte antigen receptor to the genes responsible for cell proliferation and immune function: the missing link. Annu Rev Immunol 1990;8:421-52.

[11] Abe E, De Waal Malefyt R, Matsuda I, Arai K, Arai N. An 11-base-pair sequence motif apparently unique to the human interleukin 4 gene confers responsiveness to T-cell activation signals. Proc Natl Acad Sci U S A 1992;89:2864-8.

[12] Miyatake S, Shlomai J, Arai K, Arai N. Characterization of the mouse granulocyte-macrophage colony-stimulating factor (GM-CSF) gene promoter: nuclear factors that interact with an element shared by three lymphokine genes-those for GM-CSF, interleukin-4 (IL-4), and IL-5. Mol Cell Biol 1991;11:5894-901.

[13] Berridge MJ. Inositol triphosphate and calcium signalling. Nature 1993;361:315-25.

[14] Tsuboi A, Muramatsu M, Tsutsumi A, Arai K, Arai N. Calcineurin activates transcription from the GM-CSF promoter in synergy with either protein kinase C or NF-B/AP-1 in T cells. Biochem Biophys Res Commun 1994;199:1064-72.

[15] Giacomini G, Tabibzadeh SS, Satyaswaroop PG, Bonsi L, Vitale L, Bagnara GP, Strippoli P, Jasonni VM. Epithelial cells are the major source of biologically active granulocyte macrophage colony-stimulating factor in human endometrium. Hum Reprod 1995;10:3259-63.

[16] Robertson SA, Mayrhofer G, Seamark RF. Ovarian steroid hormones regulate granulocyte-macrophage colony-stimulating factor synthesis by uterine epithelial cells in the mouse. Biol Reprod 1996;54:183-96.

[17] Robertson SA, Mayrhofer G, Seamark RF. Uterine epithelial cells synthesize granulocyte-macrophage colony-stimulating factor and interleukin-6 in pregnant and nonpregnant mice. Biol Reprod 1992;46:1069-79.

[18] Szego CM, Roberts SA. Steroid action and interaction in uterine metabolism. Recent Prog Horm Res 1953;8:419-60.

[19] Tchernitchin AN. Eosinophil-mediated non-genomic parameters of estrogen stimulation-a separate group of responses mediated by an independent mechanism. J Steroid Biochem 1983;19:95-100.

[20] Karsch FJ, Legan SJ, Ryan KD, Foster DL. Importance of estradiol and progesterone in regulating LH secretion and estrous behavior during the sheep estrous cycle. Biol Reprod 1980;23:404-13.

[21] Killen JH, Christenson RK, Ford JJ. Ovarian follicular changes after weaning in sows. J Anim Sci 1992;70:2801-8.

[22] Kojima N, Stumpf TT, Cupp AS, Werth LA, Robeson MS, Wolfe MW, Kittok RJ, Kinder JE. Exogenous progesterone and progestins as used in estrous synchrony regimens do not mimic the corpus luteum in regulation of luteinizing hormone and 17 $\beta$-estradiol in circulation of cows. Biol Reprod 1992;47:1009-17.

[23] Chomzynski P, Sacchi N. Single-step method of RNA isolation by acid guanidiniun thiocynate-phenolchloroform extraction. Anal Biochem 1987;162:156-9.

[24] Sambrook J, Fritsch EF, Maniatis T. Molecular cloning: a laboratory manual, vol. 2. 2nd ed. New York: Cold Spring Harbor Laboratory Press, 1989.

[25] Nephew KP, Whaley AE, Christenson RK, Imakawa K. Differential expression of distinct mRNAs for ovine trophoblast protein-1 and related sheep type I interferons. Biol Reprod 1993;48:768-78.

[26] McInnes CJ, Haig DM. Cloning and expression of a cDNA encoding ovine granulocyte-macrophage colony-stimulating factor. Gene 1991;105:275-9.

[27] Sanger F, Nicklen S, Coulson AR. DNA sequencing with chain-terminating inhibitors. Proc Natl Acad Sci U S A 1977;74:5463-7.

[28] Gilliland G, Perrin S, Bunn HF. Competitive PCR for quantitation of mRNA. In: Innis MA, Gelfand DH, Sninsky JJ, White TJ, editors. PCR protocols - a guide to methods and application. San Diego: Academic Press, 1990. p. 60-9.

[29] Wang AM, Mark DF. Quantitative PCR. In: Innis MA, Gelfand DH, Sninsky JJ, White TJ, editors. PCR protocol—a guide to methods and application. San Diego: Academic Press, 1990. p. 70-5. 
[30] SAS. SAS/STAT Users' guide, statistics. Cary, NC: Statistical Analysis Institute Inc., 1987.

[31] Kitamura T, Tange T, Terasawa T, Chiba S, Kuwaki T, Miyagawa K, Piao Y-F, Miyazono K, Urabe A, Takaku F. Establishment and characterization of a unique human cell line that proliferates dependently on GM-CSF, IL-3, or erythropoietin. J Cell Physiol 1989;140:323-34.

[32] Hopp TP, Woods KR. Prediction of protein antigenic determinants from amino acid sequences. Proc Natl Acad Sci USA 1981;78:3824-8.

[33] Hopp TP, Woods KR. A computer program for predicting antigenic determinants. Mol Immunol 1983;20: 483-9.

[34] Monfardini C, Kieber-Emmons T, VonFeldt JM, O’Malley B, Rosenbaum H, Godillot AP, Kaushansky K, Brown CB, Voet D, McCallus DE, Weiner DB, Williams WV. Recombinant antibodies in bioactive peptide design. J Biol Chem 1995;270:6628-38.

[35] Goodman RL, Legan SJ, Ryan KD, Foster DL, Karsch FJ. Two effects of estradiol that normally contribute to the control of tonic LH secretion in the ewe. Biol Reprod 1980;23:415-22.

[36] Iwai Y, Akahane K, Pluznik DH, Cohen RB. Ca ${ }^{2+}$ ionophore A23187-dependent stabilization of granulocytemacrophage colony-stimulating factor messenger RNA in murine thymoma EL-4 cells is mediated through two distinct regions in the 3'-untranslated region. J Immunol 1993;150:4386-94.

[37] Emond V, Asselin E, Fortier MA, Murphy BD, Lambert RD. Interferon-tau stimulates granulocyte-macrophage colony-stimulating factor gene expression in bovine lymphocytes and endometrial stromal cells. Biol Reprod 2000;62:1728-37. 